\title{
[5.
}

\section{Ethanol Extract, Ethyl Acetate Extract, Ethyl Acetate Fraction, and n-Heksan Fraction Mangosteen Peels (Garcinia mangostana L.) As Source of Bioactive Substance Free-Radical Scavengers}

\section{Ekstrak etanol, Ekstrak etil asetat, Fraksi etil asetat, dan Fraksi n-heksan Kulit Manggis (Garcinia mangostana L.) Sebagai Sumber Zat Bioaktif Penangkal Radikal Bebas}

\author{
Liza Pratiwi $^{1 *}$, Achmad Fudholi ${ }^{2}$, Ronny Martien ${ }^{2}$, Suwidjiyo Pramono ${ }^{2}$ \\ ${ }^{1}$ Fakultas Kedokteran, Universitas Tanjungpura, Pontianak; \\ ${ }^{2}$ Fakultas Farmasi, Universitas Gadjah Mada, Yogyakarta; \\ *email Korespondens: 1yza_pratiwi@yahoo.com
}

\begin{abstract}
Mangosteen peels (Garcinia mangostana L.) is well known as an excellent source of antioxidative compounds. The name of mangosteen is xanthone. Antioxidant of mangosteen peels can be extracted by ethanol, etyl acetate and can be fractinated by etyl acetate and n-hexane. The aim of this research was to compare the antioxidant activity of the peel extract by ethanol and etyl acetate and fractinated by etyl acetate and n-hexane. Extract and fraction exhibited higher scavenging activity of DPPH. The purpose of this study was to compare antioxidant activity of ethanol extract, ethyl acetate extract, fraction of ethyl acetate and n-hexane fraction. The antioxidant activity test using DPPH method with UV-Vis spectrophotometer. Ethanol extract shown IC50 value 5,03 $\mu \mathrm{g} / \mathrm{mL}$, ethyl acetate extract shown IC50 value $41,56 \mu \mathrm{g} / \mathrm{mL}$. Ethyl acetate fraction shown IC50 value $2,78 \mu \mathrm{g} / \mathrm{mL}$, and $\mathrm{n}$-hexane fraction with IC50 $22,33 \mu \mathrm{g} / \mathrm{mL}$. It means peel extract and fraction by mangosteen peels has very strong antioxidant activity and ethyl acetate fraction that its antioxidant activity higher that the other solvent.
\end{abstract}

Keywords: mangosteen peels, antioxidant, xanthone, DPPH, IC50

\begin{abstract}
Abstrak: Kulit manggis (Garcinia mangostana L.) merupakan sumber antioksidan yang baik. Mangostin yang utama adalah xanton. Kulit manggis sebagai senyawa antioksidan dapat diperoleh melalui ekstraksi dengan etanol, etil asetat dan dapat difraksinasi dengan etil asetat dan n-heksan. Ekstrak dan fraksi kulit manggis diduga memiliki aktivitas menangkal radikal bebas terhadap DPPH. Penelitian ini memiliki tujuan untuk membandingkan aktivitas antioksidan ekstrak etanol, ekstrak etil asetat, fraksi etil asetat dan fraksi n-heksan dari kulit manggis. Pengujian aktivitas antioksidan pada penelitian ini menggunakan metode DPPH dengan alat spektrofotometer UV-Vis. Ekstrak etanol
\end{abstract}


Memiliki nilai IC50 5,03 $\mu \mathrm{g} / \mathrm{mL}$, ekstrak etil asetat dengan nilai IC50 41,56 $\mu \mathrm{g} / \mathrm{mL}$. Fraksinasi dengan etil asetat menunjukkan nilai IC50 sebesar $2,78 \mu \mathrm{g} / \mathrm{mL}$, dan fraksi nheksana memiliki IC50 sebesar 22,33 $\mu \mathrm{g} / \mathrm{mL}$. Hal tersebut menunjukkan bahwa ekstrak dan fraksi kulit manggis memiliki aktivitas antioksidan yang sangat kuat dan ekstrak etanol memiliki aktivitas antioksidan lebih tinggi dibandingkan pelarut lainnya.

Kata kunci: kulit manggis, antioksidan, xanton, DPPH, IC50.

\section{Pendahuluan}

Penuaan terjadi pada hampir semua sistem tubuh manusia dan umumnya semua sistem tidak mengalami kemunduran dalam waktu yang bersamaan. Seiring dengan perkembangan ilmu dan teknologi secara ilmiah menemukan bahwa proses penuaan dapat diperlambat(Thappa dan Konda, 2013). Proses yang mempengaruhi penuaan dipengaruhi oleh faktor intrinsik dan ekstrinsik. Faktor ekstrinsik sering menyebabkan penuaan dini kulit (premature skin aging). Penuaan yang dikarenakan sinar ultraviolet (UV) disebut sebagai photoaging. Faktor lingkungan yang paling berperan adalah radiasi sinar ultraviolet. Sinar UV dapat menginduksi radikal bebas sehingga menimbulkan penuaan seluler(Athawale dkk., 2011), selain itu juga menyebabkan kerusakan kulit yang terjadi pada komponen epidermis, dermis maupun jaringan appendages kulit. Salah satu perubahan yang terjadi pada lapisan dermis kulit yang mengalami photoaging adalah berkurangnya jumlah serat kolagen, antioksidan dapat menghambat proses ini (Sahu dkk., 2013).

Antioksidan merupakan molekul yang dapat bekerja pada kulit untuk mengurangi efek radical oxygen spesies (ROS). Antioksidan dapat merangsang produksi kolagen dermis dengan meningkatkan produksi Tissue Inhibitor of Matrix Metalloproteinase-I di dermis yang berfungsi untuk menghambat pemecahan kolagen-1. Banyak produk perawatan kulit yang menggunakan antioksidan seperti vitamin C, vitamin E, ferulic acid, koenzim Q10, teh hijau(Baumann, 2005). Salah satu tanaman Indonesia yang dapat dimanfaatkan sebagai photoaging adalah manggis (Garcinia mangostana L) khususnya pada bagian kulitnya.

Tanaman manggis berasal dari hutan tropis di wilayah Asia Tenggara, salah satunya Indonesia. Penggunaan secara tradisional telah menggunakan kulit manggis sebagai masker untuk menyegarkan, melembabkan dan mengencangkan kulit(Suyanti, 2007). Kulit manggis kaya akan xanton(Akao dkk., 2008). Xanton utama adalah mangostin. Priya dkk,. mengekstraksi kulit manggis menemukan kandungan xanton, isoflavon, tannin, dan flavonoid (Priya dkk., 2010). Pelarut sangat berpengaruh pada penyarian senyawa aktif sehingga dengan pemakaian pelarut yang berbeda dapat diketahui pelarut yang memiliki aktivitas antioksidan yang paling tinggi serta nilai IC50 yang paling kecil. Penelitian ini dilakukan untuk mengetahui aktivitas antioksidan dari ekstrak etanol, ekstrak etil asetat, fraksi etil asetat dan fraksi n-heksan terhadap radikal bebas dengan metode DPPH. 


\section{Bahan dan Metode}

Bahan yang digunakan pada penelitian ini adalah: kulit manggis (Kaligesing, Purworejo), DPPH (Sigma Aldrich), Etanol 70\% (Bratachem), n-heksan (Bratachem), Etil Asetat (Bratachem), Aquadest (Dwicentra), metanol (Merck). Adapun metode penelitian adalah sebagai berikut:

\subsection{Uji Akurasi (Kecermatan)}

Kecermatan ditentukan dengan metode simulasi (spiked placebo recovery). Pada metode ini, digunakan larutan DPPH dengan konsentrasi $16 \mu \mathrm{g} / \mathrm{mL}, 18 \mu \mathrm{g} / \mathrm{mL}, 20 \mu \mathrm{g} / \mathrm{mL}, 22 \mu \mathrm{g} / \mathrm{mL}$, dan $24 \mu \mathrm{g} / \mathrm{mL}$ masing-masing sebanyak $10 \mathrm{~mL}$. Sebanyak $3 \mathrm{~mL}$ DPPH dengan berbagai konsentrasi yang telah dibuat tersebut diukur absorbansinya menggunakan spektrofotometer UV-Vis. Zeroing awal menggunakan metanol p.a $3 \mathrm{~mL}$. Akurasi (kecermatan) dinyatakan dengan persen perolehan kembali (\% recovery) yakni rasio antara konsentrasi DPPH hasil pengukuran dengan konsentrasi DPPH yang sebenarnya(Harmita, 2004).

\subsection{Presisi (Keseksamaan)}

Keseksamaan ditentukan dengan metode keterulangan (repeatibility). Pada metode ini, digunakan larutan DPPH dengan konsentrasi $22 \mu \mathrm{g} / \mathrm{mL}$ sebanyak $25 \mathrm{~mL}$. Keseksamaan dilakukan dengan mengukur absorbansi dari $3 \mathrm{~mL}$ larutan standar DPPH $22 \mu \mathrm{g} / \mathrm{mL}$ menggunakan spektrofotometer UV-Vis sebanyak 6 kali pengulangan. Zeroing awal menggunakan metanol p.a $3 \mathrm{~mL}$.

\subsection{Pembuatan Larutan DPPH 100 ppm}

Sebanyak $5 \mathrm{mg}$ DPPH dilarutkan dengan metanol $50 \mathrm{~mL}$ tambahkan metanol sampai tanda batas sehingga diperoleh larutan dengan konsentrasi 100 ppm(Supiyanti, 2010).

\subsection{OptimasiPanjangGelombang DPPH}

Sebanyak 2 mL larutan DPPH 100 ppm dimasukan kedalam labu ukur 10 mL, cukupkan hingga tanda batas dan homogenkan hingga didapat larutan DPPH dengan konsentrasi 20 ppm. Sebagai blanko digunakan metanol. Larutan kemudian ditentukan spektrum serapannya pada panjang gelombang 400-800 nm serta ditentukan panjang gelombang optimumnya (Supiyanti, 2010).

\subsection{PembuatanLarutan DPPH 0,1 $\mathrm{mM}$}

Kristal DPPH ditimbang secara seksama sebanyak 1,97 mg kemudian dimasukkan ke dalam labu ukur $50 \mathrm{~mL}$ dan ditambahkan pelarut metanol p.a sampai hingga mencapai volume $50 \mathrm{~mL}$ kemudian dihomogenkan. Larutan DPPH yang telah dibuat harus segera digunakan dan dijaga agar terlindung dari cahaya (Nurliyana, 2010). 


\subsection{Penentuan Panjang Gelombang Maksimum Larutan DPPH 0,1 mM}

Pengujian aktivitas antioksidan fraksi etil asetat kulit manggis diawali dengan penentuan panjang gelombang maksimum ( $\left.\lambda_{\text {maks }}\right)$ DPPH $0,1 \mathrm{mM}$ dalam metanol menggunakan spektrofotometri UV-Vis. Larutan tersebut dibaca serapannya pada panjang gelombang 400-800 nm(Molyneux, 2004).

\subsection{Pembuatan Larutan Baku Sampel}

Sebanyak $100 \mathrm{mg}$ sampel uji ditimbang secara seksama, dimasukkan ke dalam labu ukur $10 \mathrm{~mL}$ dilarutkan dengan metanol p.a lalu volumenya dicukupkan dengan metanol hingga mencapai volume $10 \mathrm{~mL}$ dengan konsentrasi $10.000 \mu \mathrm{g} / \mathrm{mL}$ (konsentrasi 1\%). Larutan induk ini selanjutnya digunakan untuk pembuatan larutan uji pada lima konsentrasi larutan uji yaitu 5 $\mu \mathrm{g} / \mathrm{mL}, 13 \mu \mathrm{g} / \mathrm{mL}, 25 \mu \mathrm{g} / \mathrm{mL}, 37 \mu \mathrm{g} / \mathrm{mL}$ dan $50 \mu \mathrm{g} / \mathrm{mL}$ (Mardawati dkk., 2008).

\subsection{Pembuatan Larutan Uji Sampel}

Masing-masing sampel uji ditimbang secara seksama, dimasukkan ke dalam labu ukur $10 \mathrm{~mL}$ dilarutkan dengan metanol hingga mencapai volume $10 \mathrm{~mL}$. Larutan uji menggunakan berbagai konsentrasi uji(Mardawati dkk., 2008).

\subsection{Pengukuran Absorbansi Peredaman Radikal Pada Fraksi Etil Asetat Kulit Manggis}

Sebanyak $1 \mathrm{~mL}$ fraksi (dengan berbagai konsentrasi) ditambahkan ke dalam $2 \mathrm{~mL}$ DPPH 0,1 mM. Campuran selanjutnya dikocok dan diinkubasi pada suhu kamar selama 30 menit di tempat gelap. Larutan ini selanjutnya diukur absorbansinya pada panjang gelombang yang telah didapatkan pada tahap sebelumnya dengan menggunakan spektrofotometer UV-Vis. Perlakuan yang sama juga dilakukan untuk larutan blanko (larutan DPPH yang tidak mengandung bahan uji). Larutan blanko terdiri dari $2 \mathrm{~mL}$ DPPH $0,1 \mathrm{mM}$ dan $1 \mathrm{~mL}$ metanol p.a. Zeroing awal dilakukan dengan menggunakan metanol p.a 3 mL(Nurliyana, 2010).

\section{Hasil dan Pembahasan}

\subsection{Pengumpulan dan Pengolahan Sampel}

Sampel yang digunakan dalam penelitian ini adalah kulit buah manggis. Jumlah simplisia kulit manggis yang diperoleh setelah melalui tahap pengolahan memiliki bobot $1.650 \mathrm{~g}$ atau memiliki nilai rendemen sebesar 74,0909 \% dari bobot sampel buah keseluruhan. Nilai rendemen tersebut dipengaruhi oleh beberapa faktor, diantaranya yakni jumlah kandungan air yang cukup tinggi, baik dalam buah utuh maupun kulitnya.

\subsection{Ekstraksi Kulit Buah Manggis}


Pelarut yang digunakan pada ekstraksi kulit manggis menggunakan dua pelarut yang berbeda bertujuan untuk mengetahui nilai $\mathrm{IC}_{50}$ yang lebih kecil atau memiliki aktivitas antioksidan yang kuat. Ekstrak etanol 70\% yang didapat setelah pemekatan adalah sebanyak 290,0346 g atau dengan nilai rendemen sebesar 17,5778 \% dari jumlah simplisia. Ekstrak etil asetat yang didapat setelah pemekatan adalah sebanyak 3,3423 g atau dengan nilai rendemen sebesar 3,3423\% dari jumlah simplisia. Nilai rendemen menunjukkan seberapa besar jumlah kandungan yang dapat terekstraksi oleh pelarut dalam persen (\%). Salah satu faktor yang mempengaruhi besarnya nilai rendemen adalah proses ekstraksi.

Pemilihan metode ekstraksi dalam penelitian ini didasarkan atas sensitivitas senyawa antioksidan terhadap suhu yang tinggi, oleh karena itu dipilih metode maserasi, dimana metode ekstraksi ini dilakukan tanpa pemanasan serta dilakukan dalam suhu ruangan. Prinsip ekstraksi dengan metode maserasi adalah terjadinya proses difusi larutan penyari ke dalam sel tumbuhan yang mengandung senyawa aktif. Difusi tersebut mengakibatkan tekanan osmosis dalam sel menjadi berbeda dengan keadaan di luar sel. Sehingga senyawa yang memiliki kepolaran yang sama dengan pelarut kemudian terdesak keluar karena adanya perbedaan tekanan osmosis di dalam sel dan di luar sel (Dean, 2009).

Pelarut yang digunakan dalam proses ekstraksi ini adalah etanol 70\% dan etil asetat. Pemilihan pelarut etanol $70 \%$ sebagai pelarut maserasi didasarkan atas penyarian yang optimal sehingga diharapkan banyak senyawa aktif yang terkandung didalamnya, sedangkan pelarut etil asetat yang memiliki sifat semi polar diharapkan mampu menyari senyawa xanton yaitu $\alpha$-mangostin. Dengan penggunaan kedua pelarut yang berbeda pada ekstraksi kulit manggis bertujuan dapat dihasilkan nilai $\mathrm{IC}_{50}$ yang lebih kecil atau memiliki aktivitas antioksidan yang kuat.

\subsection{Fraksi Etil Asetat dan n-Heksana Kulit Manggis}

Fraksi etil asetat yang diperoleh dalam penelitian ini memiliki bobot 5,9352 g atau memiliki nilai rendemen sebesar 5,9352\% dari ekstrak etanol 70\% dan fraksi n-heksana yang diperoleh dalam penelitian ini memiliki bobot $0,3174 \mathrm{~g}$ atau memiliki nilai rendemen sebesar $0,3174 \%$ dari ekstrak etanol 70\%. Jumlah ekstrak yang terfraksi oleh pelarut etil asetat dan n-heksana memiliki jumlah rendemen yang relatif kecil. Hal ini dimungkinkan oleh sedikitnya jumlah kandungan yang bersifat non-polar yang dapat tersari oleh etil asetat dan n-heksana dari ekstrak etanol $70 \%$. Tujuan dari tahap fraksinasi adalah untuk memisahkan senyawa berdasarkan tingkat kepolaran yang berbeda dalam dua pelarut yang memiliki tingkat kepolaran yang berbeda pula. Fraksinasi dengan ekstraksi cair-cair dilakukan dengan pengocokan. Prinsip pemisahan pada proses fraksinasi adalah didasarkan pada perbedaan tingkat kepolaran dan perbedaan bobot jenis antara dua fraksi. 


\subsection{Akurasi dan Presisi}

Akurasi merupakan ukuran yang menunjukkan derajat kedekatan hasil analisis dengan kadar analit sebenarnya. Akurasi dinyatakan sebagai persentase perolehan kembali (\% recovery) analit yang ditambahkan. Penetapan akurasi digunakan sedikitnya lima sampel yang mengandung analit dan placebo yang harus disiapkan Persamaan regresi yang didapat selanjutnya digunakan untuk memperoleh persen perolehan kembali (\%recovery). Persen perolehan kembali diperoleh dengan membandingkan konsentrasi DPPH sebenarnya dengan konsentrasi DPPH yang diperoleh berdasarkan hasil pengukuran oleh spektroforometer UV-Vis. Berdasarkan tabel diatas, nilai \% perolehan kembali yang didapat berkisar antara 98,5478 \% hingga 101,702\%. Hal tersebut sesuai dengan syarat persentase perolehan kembali untuk analit pada sampel dalam kisaran 0,001\% hingga 0,0099\% atau 10-99 ppm, yaitu 90-107 \% (Harmita, 2004).

Presisi dengan metode keterulangan, yaitu parameter yang digunakan untuk melihat seberapa baik metode analisis yang digunakan. Presisi dinilai melalui konsentrasi DPPH hasil pengukuran menggunakan spektrofotometer UV-Vis. Konsentrasi DPPH yang digunakan yaitu 22 ppm sebanyak enam replika sampel yang diambil dari larutan induk yang sama. Konsentrasi hasil perhitungan diperoleh dengan menggunakan persamaan regresi yang telah diperoleh sebelumnya pada parameter akurasi. Nilai yang telah diperoleh tersebut selanjutnya dimasukkan ke dalam persamaan simpangan baku dan diperoleh simpangan baku (SD) sebesar 0,2398. Nilai SD tersebut digunakan untuk memperoleh nilai simpangan baku relatif (RSD). RSD yang diperoleh pada pengukuran presisi adalah sebesar 1,0668\%. Nilai yang diperoleh ini tergolong baik, karena nilai RSD lebih kecil dari $16 \%$. Menurut Harmita (2004), RSD meningkat seiring dengan menurunnya konsentrasi analit, dan analit dengan kadar per sejuta $(1 \mu \mathrm{g} / \mathrm{mL})$ memiliki syarat nilai RSD yang baik adalah lebih kecil dari $16 \%$. Berdasarkan hasil yang diperoleh dapat disimpulkan bahwa sistem operasional alat dan analisis memiliki nilai presisi yang baik terhadap metode dengan respon yang relatif konstan.

\subsection{Uji Aktivitas Ekstrak Etanol Kulit Manggis}

Penentuan nilai aktivitas antioksidan dilakukan dengan menggunakan metode kuantitatif penangkapan radikal DPPH. Prinsip metode pengukuran aktivitas antioksidan secara kuantitatif ini adalah pengukuran penangkapan radikal DPPH oleh suatu senyawa yang mempunyai aktivitas antioksidan dengan menggunakan spektrofotometri UV-Vis. Hasil spektra UV-Vis pada pengujian menunjukkan bahwa nilai panjang gelombang yang berada pada 515,5 nm dan termasuk dalam kisaran panjang gelombang sinar tampak(Gandjar dan Rohman, 2009).

Hasil penelitian menunjukkan adanya aktivitas peredaman radikal DPPH, yang dilihat dari adanya penurunan nilai absorbansi radikal DPPH yang disebabkan oleh sampel uji pada berbagai konsentrasi dan semakin meningkatnya nilai persen (\%) aktivitas antioksidan. Hal tersebut juga terlihat secara kasat mata dengan adanya perubahan warna ungu yang semakin memudar dan menjadi agak kekuningan setelah masa inkubasi 30 menit. Perubahan warna ini terjadi dikarenakan adanya senyawa dalam sampel yang mendonorkan atom hidrogen kepada radikal DPPH sehingga tereduksi menjadi bentuk yang lebih stabil yaitu DPPH-H (1,1-difenil-2- 
pikrilhidrazin).Dari hasil pengukuran ekstrak etanol kulit buah manggis menunjukan bahwa semakin tinggi konsentrasi sampel yang digunakan, maka semakin rendah nilai absorbansi dari larutan DPPH dalam metanol.

Parameter yang dipakai untuk menunjukan aktivitas antioksidan adalah harga konsentrasi efisien atau efficient concentration $\left(\mathrm{EC}_{50}\right)$ atau Inhibitory Concentration $\left(\mathrm{IC}_{50}\right)$ yaitu konsentrasi suatu zat antioksidan yang dapat menyebabkan 50\% DPPH kehilangan karakter radikal atau konsentrasi suatu zat antioksidan yang memberikan persen peredaman sebesar $50 \%$. Suatu senyawa dikatakan sebagai antioksidan sangat kuat apabila nilai $\mathrm{IC}_{50}$ kurang dari $50 \mu \mathrm{g} / \mathrm{ml}$, kuat apabila nilai $\mathrm{IC}_{50} 50-100 \mu \mathrm{g} / \mathrm{ml}$, sedang apabila nilai $\mathrm{IC}_{50}$ berkisar antara $100-150 \mu \mathrm{g} / \mathrm{ml}$, dan lemah apabila nilai $\mathrm{IC}_{50}$ berkisar antara $150-200 \mu \mathrm{g} / \mathrm{ml}$. Nilai $\mathrm{IC}_{50} 200-1.000 \mu \mathrm{g} / \mathrm{ml}$ dinyatakan kurang aktif namun masih berpotensi sebagai antioksidanMolyneux, 2004).Berdasarkan hasil penelitian, nilai IC50 ekstrak etanol adalah 5,030 $\mu \mathrm{g} / \mathrm{mL}$ sehingga masuk kedalam kategori antioksidan yang sangat kuat.

\subsection{Uji Aktivitas Antioksidan Ekstrak Etil Asetat Kulit Manggis}

Kandungan utama dari kulit manggis yang memiliki aktivitas antioksidan adalah xanton yaitu $\alpha$ mangostin yang memiliki sifat semi polar. Penyarian senyawa aktif dengan menggunakan pelarut etil asetat sehingga diperoleh ekstrak diharapkan memiliki aktivitas antioksidan yang tinggi.Cairan pelarut dalam proses pembuatan ekstrak adalah pelarut yang baik (optimal) untuk senyawa kandungan yang berkhasiat atau yang aktif, dengan demikian senyawa tersebut dapat dipisahkan dari bahan dan dari senyawa kandungan lainnya, serta ekstrak hanya mengandung sebagian besar senyawa kandungan yang diinginkan. Faktor utama untuk pertimbangan pada pemilihan cairan penyari adalah selektivitas, kemudahan bekerja dan proses dengan cairan tersebut, ekonomis, ramah lingkungan dan keamanan(Depkes RI, 2000).Berdasarkan nilai IC50 diketahui bahwa ekstrak etil asetat kulit manggis memiliki persentase penghambatan terhadap radikal bebas yang cukup besar dalam rentang 46,67-90,47\% dan memiliki nilai IC50 sebesar $41,46 \mu \mathrm{g} / \mathrm{mL}$ sehingga merupakan antioksidan yang sangat kuat.

\subsection{Uji Aktivitas Antioksidan Fraksi Etil Asetat Kulit Manggis}

Fraksinasi merupakan prosedur pemisahan yang bertujuan untuk memisahkan golongan utama yang lain. Pemisahan jumlah dan jenis senyawa menjadi fraksi yang berbeda yang bergantung pada jenis simplisia. Senyawa-senyawa bersifat polar akan masuk dalam pelarut polar, begitu pula senyawa yang bersifat non-polar akan masuk kepelarut non-polar (Harborne, 1987). Kandungan utama kulit manggis yang potenial sebagai senyawa antioksidan adalah xanton yaitu $\alpha$-mangostin.

Diduga bahwa golongan senyawa yang memberikan aktivitas antioksidan dalam fraksi etil asetat kulit manggis adalah fenolik dan flavonoid. Menurut Gusrav, senyawa flavonoid berperan sebagai antioksidan karena memiliki gugus hidroksil yang dapat melepaskan proton dalam bentuk ion hidrogen. Ion hydrogen hanya memiliki satu buah proton dan tidak memiliki elektron, sehingga dalam electron radikal yang terdapat pada atom nitrogen di senyawa DPPH berikatan 
dengan ion hydrogen dan menghasilkan DPPH yang tereduksi (Gusrav dkk., 2007). Radikal pada DPPH dapat tereduksi ketika bereaksi dengan donor hidrogen yang terdapat dalam senyawa fenolik (Arazo dkk., 2011).

Berdasarkan hasil penelitian, pada fraksi etil asetat diperoleh nilai IC50 paling kecil diantara lainnya yaitu $2,78 \mu \mathrm{g} / \mathrm{mL}$ yang artinya aktivitas antioksidan fraksi etil asetat paling tinggi dibandingkan aktivitas antioksidan pada ekstrak etanol, ekstrak etil asetat, fraksi n-heksan dan residu. Pada penelitian sebelumnya yang telah dilakukan oleh $\mathrm{Wu}$ dkk yang telah menguji aktivitas antioksidan pada Receptaculum Nelumbinis, dimana fraksi butanol dari Receptaculum Nelumbinis memiliki aktivitas antioksidan yang lebih kuat dibandingkan dengan aktivitas antioksidan pada ekstraknya (Wu dkk., 2012). Hal tersebut disebabkan oleh aktivitas antioksidan dari senyawa fenolik dan flavonoid. Demikian pula pada penelitian yang dilakukan oleh Das dkk yang membandingkan aktivitas antioksidan pada ekstrak etanol, fraksi kloroform, fraksi etil asetat, dan fraksi polar dari daun dan batang Crescentia cujete. Hasil penelitian menunjukkan pada fraksi etil asetat baik pada daun maupun batang memiliki nilai IC50 yang paling kecil yang artinya memiliki aktivitas penghambatan terhadap radikal bebas yang paling besar (Das dkk., 2014).

\subsection{Uji Aktivitas Antioksidan Fraksi n-heksana Kulit Manggis}

Pada fraksi n-heksan, diduga golongan senyawa yang memberikan aktivitas antioksidan adalah alkaloid, flavonoid dan steroid. Senyawa flavonoid berperan sebagai antioksidan karena memiliki gugus hidroksil yang dapat melepaskan proton dalam bentuk ion hidrogen. Ion hidrogen hanya memiliki satu buah proton dan tidak memiliki elektron, sehingga dalam elektron radikal yang terdapat pada atom nitrogen di senyawa DPPH berikatan dengan ion hidrogen dan menghasilkan DPPH yang tereduksi (Gusrav dkk., 2007). Namun flavonoid yang terkandung dalam fraksi n-heksana kulit manggis merupakan senyawa-senyawa yang bersifat non-polar, yang masih terikat pada gugus glikosidanya sehingga menghambat pengikatan radikal DPPH dan mengakibatkan lemahnya aktivitas antioksidan yang dihasilkan. Gugus samping yang berikatan dengan flavonoid dapat mengakibatkan penghambatan aktivitas antioksidan. Hal tersebut mengakibatkan flavonoid tidak dapat mendonasikan hidrogen dan elektron untuk menangkal radikal bebas dikarenakan terjadinya halangan sterik (Harborne dkk., 2000). Adanya gugus lain di dalam fraksi n-heksana juga dapat menyebabkan flavonoid termetilasi. Pengubahan atom $-\mathrm{H}$ menjadi gugus metil $\left(-\mathrm{CH}_{3}\right)$ melalui reaksi metilasi dapat menurunkan aktivitas antioksidan, yang disebabkan pengurangan atom $-\mathrm{H}$ yang merupakan sumber proton untuk penangkapan radikal bebas (Mikamo dkk., 2000).

Potensi antioksidan fraksi n-heksana yang tergolong kurang aktif diduga turut disebabkan oleh adanya pengganggu seperti protein, lemak dan senyawa lainnya yang dapat terlarut dalam pelarut non-polar, dalam hal ini adalah pelarut n-heksana, sehingga menghalangi proses penangkapan radikal bebas. Adanya senyawa protein atau lemak pada fraksi dapat mengganggu proses penangkapan radikal bebas oleh senyawa flavonoid. Protein atau lemak pada tumbuhan dapat memberikan atom hidrogen yang dimilikinya sehingga akan berikatan dengan radikal hidroksil pada DPPH (Pine, 1988). 
Selain flavonoid, alkaloid diduga turut bertanggung jawab dalam memberikan aktivitas antioksidan dengan mekanisme sekunder, yakni sebagai penangkap radikal bebas. Hal ini didukung dari penelitian yang telah dilakukan oleh Maiza-Benabdesselamtentang aktivitas antioksidan dari ekstrak alkaloid dua spesies fumaria (Fumaria capreolata dan Fumaria bastardii), yang menyatakan bahwa aktivitas antioksidan ekstrak alkaloid dari dua spesies Fumaria memiliki aktivitas antioksidan yang bekerja dengan mekanisme sebagai freeradical scavenger (maiza dkk., 2007).

Senyawa steroid dalam fraksi n-heksana kulit manggis diduga turut berperan dalam memberikan aktivitas antioksidan. Mekanisme yang perankan oleh steroid adalah sebagai penangkap radikal. Hal ini didukung berdasarkan penelitian oleh Cui yang menyatakan bahwa ekstrak etanol 80\% dari inonotus obliquus yang positif mengandung steroid seperti lanosterol dan ergosterol peroksida menghasilkan aktivitas antioksidan sekunder radical scavenger yang cukup aktif (Cui dkk., 2004).

Berdasarkan penelitian, hasil pengukuran aktivitas antioksidan pada fraksi n-heksana kulit manggis memiliki nilai $\mathrm{IC}_{50}$ yang lebih besar dan tergolong sangat aktif namun lebih rendah dibandingkan dengan ekstrak dan fraksi kulit manggis lainnya, yakni $22,33 \mu \mathrm{g} / \mathrm{mL}$.

Tabel 1. Nilai IC50 Ekstrak etanol, ekstrak etil asetat, fraksi etil asetat dan fraksi n-heksan kulit manggis

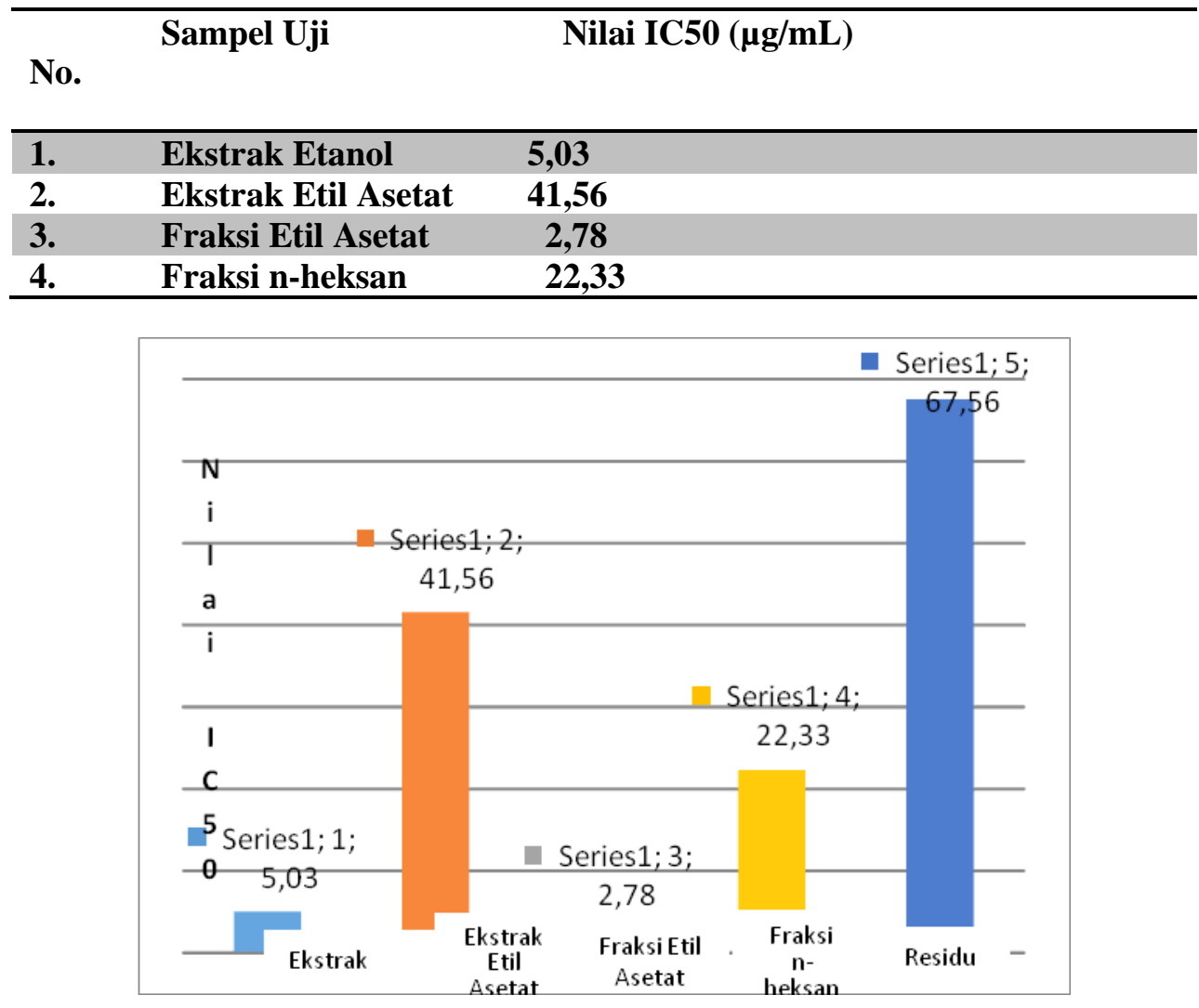

Gambar 1. Nilai IC50 ekstrak dan fraksi 


\section{Kesimpulan}

Kulit manggis memiliki aktivitas antioksidan yang sangat kuat. Aktivitas antioksidan yang paling besar dengan parameter IC50 berturut-turutadalah fraksi etil asetat, ekstrak etanol, fraksi n-heksan, dan ekstrak etil asetat.

\section{Ucapan Terimakasih}

Terima kasih kepada prodi farmasi Universitas Tanjungpura dan kepada fakultas farmasi Universitas Gadjah Mada Yogyakarta.

\section{Conflict of Interest}

Tidak terdapat potensi konflik 


\section{Daftar Pustaka}

Akao, Y., Nakagawa, Y., Linuma, M. and Nozawa, Y, 2008. Anti-Cancer Effects of Xanthones from Pericarps of Mangosteen. International Journal of Molecular Sciences.9, 355-370.

Arazo, M., Bello, A., Rastrelli, L., Montelier, M., Delgado, L., Panfet, C., dkk., 2011. Antioxidant properties of pulp and peel of yellow mangosteen fruits.Emir. J. Food Agric,23, 517-524.

Athawale, R., Salavkar, S., danTamanekar, R, 2011.Antioxidants in skin ageing - Future of dermatology. International Journal of Green Pharmacy.5, 161.

Baumann, L, 2005. How to Prevent Photoaging? Journal of Investigative Dermatology.125, 12-13.

Cui, Y., Kim, D.S., dan Park, K.C. 2004.Antioxidant Effect InonotusObliquus.J Etnopharmacol.96, 79-85.

Das, N., Islam, M.E., Jahan, N., Islam, M.S., Khan, A., Islam, M.R., dan Parvin, M.S. Antioxidant activities of ethanol extracts and fractions of Crescentia cujete leaves and stem bark and the involvement of phenolic compounds. BMC. Complementary \& Alternative Medicine. 14, 45.

Dean, J, 2009. Extraction Techniques In Analytical Science. London: John Wiley And Sons LTD, pp. 43-46.

Departemen Kesehatan Republik Indonesia, 2000. Parameter Standar UmumEkstrakTumbuhanObat. Jakarta: Departemen Kesehatan Republik Indonesia, pp. 4, 7, 9-11, 13-14, 17.

Gandjar, I.G., danRohman, A, 2009.Kimia FarmasiAnalisis. Yogyakarta: PustakaPelajar, pp. 240; 252-256; 353-355; 359-360.

Gusrav, S., Deshkar, N., Gulkari, V., Duragkar, N., danPatil, A, 2007. Free Radical Scavenging Activity of Polygala chinensis Linn. Pharmacology.2, 245-253.

Harborne J B, 1987. MetodeFitokimia: Penuntun Cara Modern MenganalisisTumbuhan. Bandung: Penerbit ITB, pp. 7-8, 49, 65, 70-72, 78, 88, 140, 156, 234.

Harmita, 2004. Petunjuk Pelaksanaan Validasi Metode dan Cara Perhitungannya,. Majalah Ilmu Kefarmasian. 1, $117-135$.

Maiza-Benabdesselam, F., Khentache, S., Bougoffa, K., Chibane, M., Adach, S., Chapeleur, Y., Max, H, 2007. Antioxidant activities of alkaloid extract of two algerian species of Fumaria: Fumariacapreolata and Fumariabastardii. Record. Nat. Prod.1, 28-35.

Mardawati, E., Filianty, F., Marta, H, 2008. Kajian Aktivitas Antioksidan Ekstrak Kulit Manggis (Garciniamangostana L) Dalam Rangka Pemanfaatan Limbah Kulit Manggis Di Kecamatan Puspahiang Kabupaten Tasikmalaya. Laporan Penelitian. UniversitasPadjajaran.

Marliana, S. D., Suryanti, V. danSuyono, 2005. Skrining Fitokimia dan Analisis Kromatografi Lapis Tipis Komponen Kimia BuahLabu Siam (SechiumeduleJacq.Swartz) dalam Ekstrak Etanol. Biofarmasi.3(1), 26-31.

Mikamo, E., Okada, Y., Semma, M., Itto, Y., dan Morimoto T, 2000.Studies on Structural Correlationship with Antioxidant Activity of Flavonoids.J. Jpn. Soc. Food Sci. Technol. 7, 97-101.

Molyneux, P, 2004. The use of the stable free radical diphenylpicrylhydrazyl (DPPH) for estimating antioxidant activity.Songklanakarin J SciTechnol. 26, 211-219.

Nurliyana, R., Syed Z.I., Mustapha S.K., Aisyah, M.R., danKamarul R.K, 2010. Antioxidant study of pulp and peel dragon fruits: a comparative study. Int. Food Res. J. 17, 365-375. 
Pine, H.S, 1988.RadikalBebas. Bandung: ITB. Terjemahandari: Organic Chemistry 2, pp. 23-26.

Priya, V., Jainu, M., Mohan, S.K., Saraswati, P.andGopan, C.S, 2010. Antimicrobial activity of pericarp extract of garciniamangosatanlinn. International Journal of Pharma Sciences and Research.1: 278-281.

Sahu, R., Matlam, M., Deshmukh, V., Dwivedi, J., Jha, A., dan Roy A, 2013. In vitro techniques to assess the proficiency of skin care cosmetic formulations. Pharmacognosy Reviews. 7, 97.

Supiyanti, W., Endang, D.W., Lia, K, 2010. Uji Aktivitas antioksidan dan Penentuan Kandungan Antosianin pada kulit buah manggis (GarciniaMangostana).MajalahObatTradisional.15, 6470.

Suyanti, Setyadjit, 2007. Teknologi Penanganan Buah Manggis Untuk Mempertahankan Mutu Selama Penyimpanan. Buletin Teknologi Pascapanen Pertanian.3, 67.

Thappa, D. danKonda, D, 2013. Age reversing modalities: An overview. Indian Journal of Dermatology, Venereology, and Leprology.79, 3.

Wu, Y.B., Zheng, L.J., Wu, J.G., Chen, T.Q, Yi, J., dan Wu, J.Z. 2012. Antioxidant activities of extract and fraction from Receptaculum Nelumbinis and Related Flavonol Glycosides. International Journal of Molecular Sciences. 13: 7163-7173. 